\title{
PERAN ACCOUNT EXECUTIVE DI ERA DIGITAL DALAM PROSES PERENCANAAN IKLAN
}

\author{
Ardiman Tampubolon \\ Glorya Agustiningsih Sitompul ${ }^{1}$
}

\begin{abstract}
The development of the advertising industry has experienced many changes over time, but as the development of the advertising industry is not followed by the development of the ability of skilled human resources in it, especially in the duties and roles of an Account Executive in an advertising company. The task of account executive in the digital era is not the same as the previous era, therefore it is necessary to have special skills and have more knowledge about the advertising industry today. The purpose of this study is to determine the development of the role of account executives in advertising companies today, which are caused by changes in the industrial era and the development of the advertising revolution in today's digital era.
\end{abstract}

Keywords: Account Management, Account Executive, Advertising.

\begin{abstract}
Abstrak
Perkembangan industri periklanan telah mengalami banyak perubahan dari waktu ke waktu, akan tetapi seiring berkembangnya industri periklanan tidak diikuti dengan berkembangnya kemampuan sumber daya manusia yang terampil di dalamnya, khususnya dalam tugas dan peran seorang Account Executive di perusahaan periklanan. Tugas account executive pada era digital ini tidaklah sama dengan era sebelumnya, oleh karena itu maka perlu suatu keterampilan khusus dan memiliki pengetahuan yang lebih mengenai industri periklanan pada masa kini. Tujuan penelitian ini adalah untuk mengetahui perkembangan peran account executive di perusahaan periklanan pada masa kini, yang disebabkan oleh faktor perubahan era industri dan perkembangan revolusi iklan di era digital masa kini.
\end{abstract}

Kata Kunci: Account Management, Account Executive, Periklanan.

\section{PENDAHULUAN}

Dunia industri periklanan kini sangat berkembang, iklan yang dulu kita hanya bisa lihat di media seperti televisi,radio, dan media cetak tetapi kini iklan itu sendiri sudah dapat dilihat di media digital. Iklan tidak disampaikan tanpa perhitungan, karena hal itu hanya akan membuang uang dengan sia-sia. Hal inilah yang membuat periklanan tidak pernah sepi sebagaimana fungsinya dalam mengenalkan produk yang memiliki sifat kegunaan yang efektif dan efisien. Produk dan jasa yang ada semakin beraneka ragam, dan dalam tahun ke tahun semakin banyak perusahaan yang berdiri dengan produk andalan mereka.

Semakin banyak persaingan yang terjadi antara kompetitor yang satu dengan kompetitor lainnya baik dalam hal mempromosikan produk atau jasa mereka maupun mengomunikasikannya kepada masyarakat.

${ }^{1}$ Alamat kini: Institut Bisnis dan Informatika Kwik Kian Gie, Jln Yos Sudarso Kav. 87 Sunter, Jakarta 14350. Penulis untuk korespodensi : Telp : (021) 65307062 Ext 705. E-mail : gloria.sitompul@kwikkiangie.ac.id 
Di tengah sengitnya persaingan dalam mengomunikasikan suatu produk atau jasa dibutuhkan strategi dan konsep iklan yang mampu menarik minat konsumen. Dalam dunia periklanan seperti ini banyak dibutuhkan biro iklan yang memiliki kualitas dan mampu bekerja secara profesional sehingga iklan yang mereka kenalkan ke khalayak akan tepat sesuai target dari produk melalui konsep iklan yang disepakati tersebut.

Eksistensi suatu biro iklan tidak luput dari klien, klien merupakan hal yang penting dalam suatu biro iklan. Pemasukan pendapatan dan keloyalan dari klien adalah sasaran utama untuk terus maju dan bertahan dalam persaingan dunia usaha dan bisnis seperti saat ini. Kualitas pelayanan yang diberikan kepada klien merupakan salah satu hal terpenting dalam mempertahankan klien dari persaingan bisnis yang dilakukan oleh kompetitor lain demi mendapatkan kepercayaan klien atau konsumen. Persaingan antar biro iklan akan selalu ada dari tahun ke tahun dengan menawarkan bentuk kerjasama yang menarik antara pihak pengiklan dengan pihak biro iklan. Peningkatan tersebut untuk mempertahankan eksistensi dari biro iklan mereka. Pemikiran tersebut tidak hanya menjadi suatu masalah bagi pemilik usaha biro iklan, melainkan seluruh elemen yang termasuk di dalamnya termasuk karyawan maupun seluruh staf yang bekerja di perusahaan biro iklan tersebut.

Persaingan biro iklan di Jakarta sangatlah ketat, permainan harga dan pelayanan yang memanjakan klien adalah cara yang digunakan oleh berbagai perusahaan periklanan, penawaran konsep dan ide-ide kreatif dalam perencanaan kampanye iklan juga merupakan aspek penting dalam mendapatkan kepercayaan dari klien. Tidak jarang, beberapa kompetitor baru menggunakan cara mencari klien baru dengan mendatangi klien dari biro lain dan menawarkan harga yang jauh lebih murah dari biro iklan lainnya tetapi kualitas pelayanan dan hasil kinerja belum tentu memuaskan.

Permasalahan ini tentunya menghasilkan suatu tindakan dari masingmasing biro iklan untuk terus menjaga dan memelihara hubungan yang baik serta intim dengan kliennya. Sejatinya bahwa pengiklan diibaratkan seorang raja yang dimana kepuasan serta kepercayaannya harus terus terjaga, karena bagi biro iklan keberhasilan kliennya dalam meningkatkan citra positif merek mereka ataupun meningkatnya penjualan dari produk mereka. Hal tersebut dianggap sebagai keberhasilan besar bagi biro iklan karena mampu memberikan hasil terbaik dalam pekerjaan yang dipercayakan oleh kliennya.

Karena umumnya perusahaan pengiklan berupaya agar produknya laku dan diminati di pasaran, peranan account executive sangat diperlukan dalam sebuah perusahaan jasa kreatif, mengingat banyaknya persaingan yang semakin ketat antar perusahaan biro iklan yang satu dengan yang lainnya guna memperebutkan pangsa pasar atau konsumen yang ada. Peran seorang account executive dituntut mampu menjadi penghubung antara biro iklan dengan klien secara profesional.

Kehadiran account executive merupakan suatu penghubung perusahaan biro iklan dengan kliennya, terutama agar tercapainya saling pengertian pesan yang disampaikan. Pada zaman saat ini yang penuh dengan kompetisi sangat ketat antara perusahaan jasa khususnya biro iklan, dan untuk memenangkan kompetisi tersebut maka biro iklan memerluka account executive yang kompeten dan memiliki pengetahuan yang luas tentang trend perkembangan iklan di era industri terbaru saat ini dalam meningkatkan kualitas layanan kepada klien yang sudah loyal maupun dalam hal mencari klien baru.

Tantangan lain yang dihadapi
perusahaan jasa periklanan adalah berkembangannya konsep periklanan dari waktu ke waktu, iklan tidak lagi menunjukan komunikasi satu arah, iklan harus memiliki nilai kognitif, iklan di massa kini harus responsif, konsep iklan kedepannya tidak akan membuat perbedaan antara titik sentuh yang mereka miliki dengan merek, dan unsur iklan di massa kini harus memilki unsur kejutan. Kepedulian seorang account executive terhadap apa yang terjadi di lingkungan internal maupun eksternal perusahaan dan juga terhadap perkembangan iklan, menuntut profesi yang mereka tekuni untuk juga terus berkembang dan meningkatkan 
pengetahuan tentang konsep iklan di massa kini dan massa depan.

Hal tersebut bertujuan agar perencanaan iklan sesuai dengan apa yang diharapkan oleh klien. Sehingga dengan tercapainya suatu tujuan bersama maka akan meningkatkan kepercayaan klien kepada perusahaan biro iklan tersebut, terlebih lagi mereka akan menjadi klien yang loyal dan terus membangun kerjasama di antara kedua belah pihak untuk kepentingan bersama. Oleh karena itu sangat penting untuk mengerti dan memahami dengan baik peran seorang account executive pada suatu perusahaan jasa, karena merekalah yang menjadi ujung tombak perusahaan dan penentu arah berkembangnya perusahaan.

\section{METODE PENELITIAN}

Penelitian ini bersifat kualitatif, artinya peneliti harus memberdayakan diri sendiri untuk berkomunikasi secara langsung dengan subjek penelitian.

Subjek dalam penelitian ini adalah General Manager dari Inexus Advertising dan Account Executive Inexus Advertising Masingmasing dari subjek penelitian adalah praktisipraktisi yang masih aktif bekerja dalam dunia industri periklanan dan media periklanan. Lebih dari itu bahwa informan yang menjadi subjek penelitian memiliki pengalaman yang lama dalam profesinya masing-masing sebagai account executive baik yang bekerja di agensi media periklanan ataupun yang bekerja langsung sebagai account executive di perusahaan pengiklan.

\section{Teknik Pengumpulan Data}

Teknik pengumpulan data dalam penelitian ini adalah wawancara mendalam, terutama kepada kedua informan. Peneliti ingin mendapatkan pengalaman mereka dan melihat lansung aktivitas mereka. Selain itu peneliti juga melakukan observasi lansung ke lapangan dengan melihat account executive mengkawal aktivitas proses perencanaan iklan dari awal hingga akhir sampai tahap produksi iklan. Untuk memperkaya dan memperkuat pembahasan pada penelitian, peneliti juga mengumpulkan data dengan studi pustaka.

Hasil penelitian ini akan berbentuk laporan yang bersifat deskriptif. Penulis akan memaparkan fakta-fakta yang diperoleh untuk kemudian memberikan suatu kesimpulan terkait peran account executive inexus advertising dalam proses perencanaan iklan.

\section{HASIL PENELITIAN}

\section{Peran Account Executive Dalam Mengulas Rencana Pemasaran Kepada Klien}

Pekerjaan account executive merupakan pekerjaan yang berada pada level pemula, yang di mana tugas utama seorang account executive adalah melakukan pendekatan dan penawaran kepada berbagai perusahaan, hingga menghasilkan sebuah kerja sama yang menguntungakan. Akan tetapi di industri media dan periklanan, peran account executive sedikit berbeda. Di mana tugas mereka untuk mencari perusahaan yang akan mengisi ruang iklan yang mereka miliki. Account executive di biro iklan dituntut untuk mampu menyakinkan calon klien maupun klien agar mampu mengeluarkan biaya pemasangan iklan yang cukup besar.

Berdasarkan analisa di atas dapat diambil sebuah hasil penelitian terhadap peran account executive di perusahaan periklanan. Aktivitas seorang account executive tak lepas dari interaksi dengan banyak orang, baik secara langsung maupun melalui telepon dan email. Karena itu, mereka harus memiliki keahlian berkomunikasi, yang meliputi kemampuan memersuasi dan bernegosiasi. Kemampuan analisis account executive juga harus memadai, mengingat ia akan banyak berurusan dengan perhitungan nilai kerja sama. Selain itu mereka juga harus menguasai ilmu pemasaran, periklanan, dan harus memiliki jiwa kepemimpinan. Dengan memiliki pengetahuan dan keterampilan seperti yang disebutkan di atas seorang account executive akan mampu menjadi mediator yang profesional bagi kedua perusahaan dan mampu mendatangkan bisnis baru bagi biro iklan. 


\section{Peran Account Executive Dalam Membantu Menganalisis Situasi Lingkungan Perusahaan Klien}

Proses pertama dari keseluruhan proses penyusunan strategi komunikasi terintegrasi adalah mengeksplorasi berbagai kondisi lingkungan bisnis. Tujuannya adalah menemukan ide-ide berharga untuk pengembangan komunikasi merek. Identifkasi pasar yang dimaksud mencakup analisis terhadap berbagai aspek tren dan perubahan di pasar mulai dari tren ekonomi dan industri, perkembangan teknologi, berbagai regulasi yang memengaruhi merek, perubahan sosial-politikbudaya, hingga isu-isu lingkungan.

Berdasarkan hasil penelitian pernyataan yang diutarakan oleh narasumber pentingnya sebuah identifikasi pasar sangatlah diperlukan untuk mengetahui kebutuhan apa yang saat ini dibutuhkan oleh pasar sehingga perusahaan dapat menciptakan produk yang dapat memenuhi kebutuhan pasar. Selain itu tujuan dilakukannya identifikasi pasar juga untuk mengetahui siapa yang menjadi pesaing, merek produk apa yang menjadi pemimpin di pasar dalam kategori tertentu.

Maka sangat perlu bagi account executive dapat membantu permasalahan klien dengan mengetahui masalah-masalah apa saja yang ada di pasar saat ini, dengan melakukan analisis terhadap lingkungan bisnis perusahaan, kebijakan pemerintah di bidang ekonomi, menganalisis permintaan pasar, dan melakukan analisis lingkungan sosial-politik-budaya.

Begitu luasnya karakteristik yang terdapat di pasar, maka segementasi pasar perlu dilakukan. Berdasarkan hasil pengatan di lapangan yang ditemukan oleh peneliti mengenai segmentasi pasar yang dijelaskan oleh account executive kepada kliennya memiliki manfaat dan tujuan seperti: (1) pasar lebih mudah dibedakan, perusahaan akan lebih mudah mencari kelompok konsumen yang sifatnya homogeny agar lebih mudah memahami selera konsumen; (2) pelayanan lebih baik, dalam hal ini terdapat empat hal penting yang diinginkan oleh konsumen dalam memenuhi kebutuhnnya yaitu kualitas, harga, pelayanan, dan ketepatan waktu; (3) strategi pemasaran lebih terarah, dengan melayani pasar yang sifatnya homogeny, maka dalam merencanakan strategi pemasaran, penyusunan bauran pemasaran yang meliputi produk, harga, distribusi, dan promosinya lebih terarah dan lebih tajam; (4) menemukan peluang baru; (5) faktor penentu desain, pemasar dapat mendesain produk sesuai dengan kebutuhan segmen tersebut dan desain yang dibuat pun lebih responsive terhadap kebutuhan pasar; (6) strategi komunikasi lebih efektif, komunikasi bisa menjadi efektif di mana perusahaan sebagai komunikator akan berkomunikasi dengan cara yang berbeda dan media yang berbeda kepada segmen pasar yang ditargetnya.

Sebelum menentukan target pasar maka harus melakukan segmentasi pasar terlebih dahulu, dengan melakukan segmentasi pasar pada proses sebelumnya maka dapat mempermudah proses kerja pemasar dalam menentukan segmen yang potensial dalam arti terdapat populasi yang cukup besar yang dapat menjamin kesinambungan produksi. Selain itu meskipun sudah memiliki segmen pasasr potensial belum tentu menjamin keberhasilan, faktor lain yang harus dipertimbangkan adalah bagaimana pemasar dapat menciptakan produk yang dapat memuaskan dan memenuhi kebutuhan konsumennya di pasar. Sehingga dengan adanya produk yang dapat memenuhi kebutuhan tersebut dengan harga yang dapat dijangkau oleh calon konsumennya. Maka produk tersebut akan memiliki daya saing dengan produk lainnya yang ada di pasar potensial tersebut.

\section{Peran Account Executive Membantu Klien Menentukan Tujuan Periklanan}

Tujuan periklanan yang ditetapkan oleh klien yang satu dengan yang lain tidaklah sama, maka dari itu sebagai account executive harus mengetahui permasalahan yang dialami oleh kliennya dalam masalah mengomunikasikan merek kepada target audiensinya nanti. Penentuan objektif dari perencanaan komunikasi merek ini nantinya juga yang akan menentukan proses selanjutnya dari tahapan perencanaan iklan. Dengan ada objektif yang tepat dan jelas, maka akan mempermudah proses penyusunan strategi kreatif, pelaksanaan strategi media, penyesuaian anggaran yang dimiliki 
klien untuk beriklan dan evaluasi dari proses eksekusi komunikasi pemasaran.

\section{Peran Dalam Memberikan Masukan Strategi Kreatif Kepada Klien}

Melaksanakan strategi kreatif tentunya harus memahami apa yang akan menjadi positioning dari pesan merek yang akan disampaikan kepada khalayak. Seperti pernyataan yang dikatakan oleh informan dalam penelitian ini bahwa sebagai orang yang bekerja di perusahaan periklanan atau biro iklan setiap individu harus bisa berpikir out of the box, yaitu mampu berpikir di luar dari hal yang sudah lazim orang pikirkan. Menemukan ide-ide kreatif yang segar dan unik yang tidak pernah terpikirkan oleh orang lain merupakan kunci utama dalam melaksanakan strategi kreatif. Seperti yang disebutkan dalam bab sebelumnya mengenai salah satu tugas seorang account executive yaitu memastikan bahwa semua bagian dari kampanye iklan mengomunikasikan pesan yang diinginkan klien dengan jelas. Oleh karena itu, maka dalam hal ini seorang account executive juga harus dapat bekerjasama dengan divisi kreatif untuk mencipakan brand soul dan selling idea dari suatu produk atau merek yang akan dikomunikasikan ke khalayak.

\section{Peran Account Executive Memberikan Rekomendasi Kepada Klien Dalam Melaksanakan Strategi Media \\ Dari analisa yang dilakukan pada} tahapan perencanaan iklan di tahap melaksanakan strategi media, mendapatkan hasil penelitian terhadap peran account executive pada tahapan tersebut yakni harus mengerti mengenai karakteristik media yang digunakan dalam kampanye iklan, karena setiap media memiliki karakteristik yang berbeda-beda dan memiliki kekuatan serta kelemahan baik media konvensional maupun digital. Beberapa tugas account executive pada masa kini pertama yaitu, mengembangkan jadwal proyek dan memastikan bahwa biaya yang terlibat ada dalam anggaran klien. Kedua, yaitu merevisi perkiraan biaya dan jadwal kegian. Kedua tugas tersebut tidak akan bisa dilakukan dengan baik dan benar oleh seorang account executive jika mereka tidak mengerti dan memahami sedikit pengetahuan mengenai media yang digunakan dalam kampanye iklan, pembagian bobot media dalam mengomunikasikan iklan, konsentrasi media yang digunakan untuk mencapai lebih banyak audiensi dan sebagainya.

\section{Peran Account Executive Dalam Melakukan Evaluasi Efektivitas Periklanan}

Peran lainnya dari seorang account executive adalah mengevaluasi keefektifan program periklanan, dan melacak angka penjualan. Dalam temuan penelitian dikatakan dengan jelas oleh informan bahwa untuk mengevaluasi suatu perencanaan kampanye iklan maka harus kembali ke tahap penentuan dari tujuan beriklan itu sendiri, apa yang ingin dicapai dengan melakukan iklan di media konvensional ataupun media digital. Setelah kembali mengacu kepada objektif beriklan itu maka proses evaluasi perencanaan iklan tersebut dilakukan pada bagian strategi komunikasi yang digunakan apakah sudah sesuai dengan KPI atau tidak, sudah memiliki preposisi dan keunikan yang berbeda dari merek kompetitor lain atau tidak dan sebagainya. Setalah itu proses evaluasi yang dilakukan seorang account executive akan melihat hasil dari program iklan tersebut terhadap peningkatan penjualan atau terhadap meningkatnya citra produk di benak masyarakat atau mungkin masyarakat tergugah untuk menjadi buzz dalam mengomunikasikan merek tersebut kepada orang lain. Hal itu semua harus dapat diubah ke dalam bentuk nilai kuantitaif yang dapat diukur, dilihat dan dipertanggung jawabkan kepada klien.

\section{KESIMPULAN}

Dalam peranannya sebagai account executive, telah bekerja dan menjalankan tugas sesuai dengan fungsinya di perusahaan periklanan. Informasi yang disampaikan sesuai dengan fakta (rasional) oleh account executive mengenai analisis pasar dan perilaku konsumen dan hal itu dapat diterima dengan baik oleh klien.

Untuk dapat memengaruhi dan memberikan rekomendasi kepada klien, seorang account executive harus dapat memformulasikan informasi ke dalam suatu pesan yang dapat diterima oleh akal sehat klien. Pada proses perencanaan iklan seorang account 
executive harus memiliki pengetahuan yang luas tentang perencanaan iklan, mengerti situasi lingkungan perusahaan calon klien maupun klien dan permasalahan yang dihadapi klien dalam mengomunikasikan produk atau jasa perusahaan tersebut kepada masyarakat.

\section{SARAN}

Account executive sebagai penghubung antara perusahaan dengan klien harus mampu mempertahankan profesionalitas agar selalu mencapai komunikasi yang efektif dan pertukaran sosial yang saling menguntungkan. Menambah jumlah sumber daya manusia account executive yang berkompeten dan terampil dalam ilmu pemasaran dan periklanan agar mampu memperluas jangkauan target dan mendatangkan bisnis baru bagi perusahaan.

Mengenali lebih dalam lagi setiap keinginan klien dengan meningkatkan analisis pada produk, kekuatan maupun kelemahan produk, target pasar dan kompetitor, dan lain sebagainya. Account executive juga harus meningkatkan kemampuan presentasi dengan menyampaikan isi perencanaan kampanye iklan dengan singkat, jelas, padat dan melayani klien dengan hati.

\section{DAFTAR PUSTAKA}

\section{Buku}

Fill, Christ (2009), Marketing Communications: interactivity, communities and content, Edisi 5, London: Prentice Hall.

Kotler, P., dan Armstrong, G (2008), Prinsipprinsip Pemasaran. Jakarta: Erlangga.

Kriyantono, Rachmat (2006), Teknik Praktis Riset Komunikasi, Jakarta: Kencana Prenada Media Group.

Kumar, Arun, C.L. Tyagi (2005), Advertising Management, India: Atlantic Publisher.

Morissan (2010), Periklanan Komunikasi Pemasaran Terpadu, Jakarta: Kencana Prenada Media Group.
Nurfebiaraning (2017), Manajemen Periklanan, Yogyakarta: CV. Budi Utama.

Pamungkas, Indra dan Novianto Adibayu (2016), Imcology, Yogyakarta: Depublish.

Sarwono, Sarlito W (2015), Teori-Teori Psikologi Sosial, Jakarta: Rajawali Pers.

Strelecky, David (2009), Careers in Focus Advertising \& Marketing Second Edition, New York: Infobase Publishing.

Sugiyono (2012), Metode Penelitian Kuantitatif Kualitatif dan R \& D, Bandung: Alfabeta.

Watono, dan Watono. 2011. IMC That Sells. Jakarta: PT. Gramedia Pustaka Utama.

West, Richard dan Lynn H. Turner (2008), Pengantar Teori Komunikasi: Analisis dan Aplikasi Buku 2, Edisi 3, Jakarta: Salemba Humanika.

\section{Skripsi}

Yuni, Fera (2015), Skripsi: Peran Account Executive dalam Membangun Kepercayaan Klien di Biro Iklan PT. Rizang Pariwara, Fakultas Ilmu Komunikasi, Universitas Islam Sultan Agung Semarang.

Bagus, Sadewo (2011), Skripsi: Peranan Account Executive Memperoleh Klien Baru dan Mempertahankan Klien Lama di CV. Transclab Multimedia \& Advertising, Fakultas Ilmu Sosial dan Ilmu Politik, Universitas Sebelas Maret Surakarta.

Rahmanto, Devian Eko (2014), Skripsi: Strategi Komunikasi Account Executive dan Media Planner OCTA Advertising, Program Studi Ilmu Komunikasi, Fakultas Ilmu Komunikasi dan Informatika, Universitas Muhammadiyah Surakarta. 